\title{
Sediment Flow Characteristics in The Upper Slope of Volcanic Landscapes With Dryland Agriculture
}

\author{
La Ode Hadini $^{1 * *}$, Junun Sartohadi ${ }^{2}$ (D), M. Anggri Setiawan ${ }^{3}$, Djati Mardiatno ${ }^{3}$ (D), \\ Nugroho Christanto ${ }^{3}$ \\ ${ }^{1}$ Department of Geography, Halu Oleo University, Kendari, 93232, Indonesia \\ ${ }^{2}$ Department of Soil Science, Faculty of Agriculture, Universitas Gadjah Mada, Yogyakarta, \\ 55281, Indonesia \\ ${ }^{3}$ Faculty of Geography, Universitas Gadjah Mada, Yogyakarta, 55281, Indonesia
}

\begin{abstract}
Received 1 June 2021/Revised 9 November 2021/Accepted 25 November 2021/Published 20 December 2021
\end{abstract}
\begin{abstract}
Increasing population densities and food demands are major factors contributing to the widespread use of agricultural drylands in upper volcanic slope areas. This phenomenon poses a high risk of severe erosional events that are environmentally hazardous. Therefore, this study aims to analyze the sediment flow characteristics, based on the relationship between sediment flow and water level as well as the sediment discharge rate and soil loss. Field surveys were conducted to determine the soil measurement, slope morphology and dryland cover characteristics. The sediment flow was evaluated at the gully outlet, where 169 suspension data pairs for the modeling and 130 suspension data pairs for the validation, as well as the bed load, water level, rainfall and water flow characteristics were obtained. Tables and figures were subsequently used to represent the measurement data and analysis results for the correlation between the flow rate effects, sediment and soil loss on the water surface. The results showed that the sediment flow in volcanic landscape slopes with dryland agriculture were possibly characterized by the polynomial relationship, using the suspension discharge model, $\mathrm{Q}_{\mathrm{s}}=0.0322 \mathrm{Q}^{2}+6.0625 \mathrm{Q}-1.2658$. Under this condition, the average rate of soil loss in the form of sediment load and erosion rate of the catchment area occurred at 953.53 and 1,657.94 ton/ha/yr, respectively. Furthermore, the sediment sources in the soil loss were believed to originate from $83 \%$ of the suspended sediments and $17 \%$ bed loads.
\end{abstract}

Keywords: Discharge; Dryland; Landscape; Sediment; Volcano

\section{Introduction}

Indonesia is home to more than 400 volcanoes, out of which 127 occur in the active category (Badan Geologi Indonesia, 2011). Also, the country's volcanic landscape exhibits a distinctive utilization pattern, starting from the cone to the upper and foot slopes (Sartohadi \& Pratiwi, 2014). The general trend shows that these regions are not exploited intensively, due to possible high-intensity fire hazards. However, the middle slope is used for agro-forestry and agriculture production activities (Nandini \& Narendra, 2010; Alstrom \& Akerman, 2016; 
Zhou et al., 2016). The land is typically developed for agricultural practices from the foot slope and downstream (Bachri et et al., 2017). Sediment flow due to the erosional process in the upper volcanic gradient appears relatively sensitive to the land use. Population pressures and food demands progressively transform the utilization of these areas into dryland agriculture. Furthermore, tropical climate with high topographic rainfall on volcanic slopes, increases the risk of soil erosion, leading to sediment flow.

Sediment flow is generally a potential source of soil loss in the watershed, and its adverse impact encompasses water quality deterioration and siltation (Panagos et al., 2015; Wulandari et al., 2014; Mondal et al., 2015). In addition, there is need to control the flow rates from the upper volcanic watershed, based on the level of tolerated soil loss for sustainable application. Various methods have been employed in predicting the soil loss ( $\mathrm{Li}$ et al., 2015; Nocoń, 2016; Maltsev \& Yermolaev, 2020), including USLE equations (Sharma et al., 2011), GEOWEPP (Maalim et al., 2013) and GSTARS4 (Ahn \& Yang, 2015). Each technique has its unique advantages and disadvantages, as viewed from various aspects, such as the research scope and scale, data input, labor, cost and time (Maalim et al., 2013; Verma \& Jha, 2015). However, certain challenges tend to occur, due to the limitations in the developing prediction methods, including the overestimation or underestimation of the real field conditions.

These weaknesses are possibly overcome through the optimization of specific forecast patterns by increasing the levels of detail on a small coverage area and simultaneously applying the key area methods. In a minimal watershed, these key area procedures have the ability to improve the prediction quality, where the sediment flow and the accompanying processes in land and channel erosion are easily observed. Sediment Delivery Ratio (SDR) is a major prediction technique that matches with the key area method. Based on this concept, the total erosion rate in watersheds is estimated by detecting the sediment flow (Ayuningtyas, 2012; Lazzari et al., 2015).

Erosion process dynamics and the watershed geophysical conditions represented by the channel outlet, are practically depicted, using hydrograph discharge and sediment grain analyses. The hydrograph discharge assessment describes the relationship between flow and sediment release by erosion determinants, while the sediment grain test provides clues to erosion sources contributing to the sediment flow. Furthermore, sediment flow has the capacity to navigate an outlet in the form of suspended and bed load sediments. The watershed specific geophysical characteristics tend to generate a unique hydrological response and sediment flow properties typical of dryland agriculture. The sediment flow 
characteristics are commonly concluded from a set of information, such as the relationship pattern between sediment flow and water level flow rate, as well as the sediment flow rate and grain size texture (Kellner \& Hubbart, 2018; Hadini et al., 2019).

Soil thickness and other associated properties, including texture (Rusdi et al., 2013), structure (Renard et al., 1977), organic matter, fertility and permeability, are used to determine the soil erodibility and, consequently, the resultant sediment flow attributes. Previous study correlated the soil depth with soil loss in karst areas, where the thin soil region demonstrated a gradual infiltration and rapid water flow (Utomo et al., 2012). This outcome produced a suspension curve of $\mathrm{Q}_{\mathrm{s}}=8.561 \mathrm{Q}^{0.893}$ and soil loss of 0.77 tons/ha/yr. Another earlier study also reported spatially typical sediment flow characteristics in various soil types, including a unique sample in Sermo reservoir (Wulandari et al., 2014). Apparently, no studies have been conducted on the physical characteristics of watershed landscapes with homogeneous land use as a key area. However, suspension flow dynamics have been analyzed extensively in basins with varied land use patterns, alongside diverse geophysical conditions, based on certain assumptions or generalizations. The results are dependent on presumed uniformity, potentially generating a bias towards the real field situations. As a consequence, investigations on sediment flow dynamics need to employ a key area approach in providing broader coverage for a minor watershed with homogeneous land use and geophysical conditions. This method further supports the planning of the basin's physical features in a more comprehensive and uniform manner, to produce a report that matches real field conditions. The key area technique also create studies that appropriately enable the generalization for other watersheds with similar characteristics.

The geophysical characteristics of a volcanic watershed appear unique, indicating possible hydrological response in the form of sediment flow and soil loss that only simulates sedimentation. Meanwhile, Bompon refers to a volcanic watershed with a soil thickness above 10 m-categorized super thick soil (Sartohadi et al., 2013). This area serves numerous purposes, in terms of agro-forestry, settlements, rice fields and dryland agriculture. The typical features of Bompon watershed are very suitable for key areas in the study of sediment flow and soil loss characteristics in volcanic landscapes for each land use. Therefore, this study aims to analyze the sediment flow in a volcanic watershed for dryland agricultural area, with several challenges, including the relationship pattern between sediment flow and water level flow rate, sediment discharge rate and soil loss, as well as the sediment source types. 


\section{Methods}

Bompon volcanic watershed along the borders of Magelang, Purworejo, and Wonosobo regency, Central Java, served as the key area (Figure 1). This region stretches between $9,163,200-916,400 \mathrm{mN}$ and $396,300-397,800 \mathrm{mE}$, with an elevation ranging from 377 up to $539 \mathrm{~m}$ above sea level and a large area of \pm 300 ha $\left(0.03 \mathrm{~km}^{2}\right)$.Uneven rainfall conditions are known to characterize its climate, due to the influence of geomorphological features. Also, between September 2015-August 2016, the average annual rainfall in Bompon attained 2,214.5 mm.

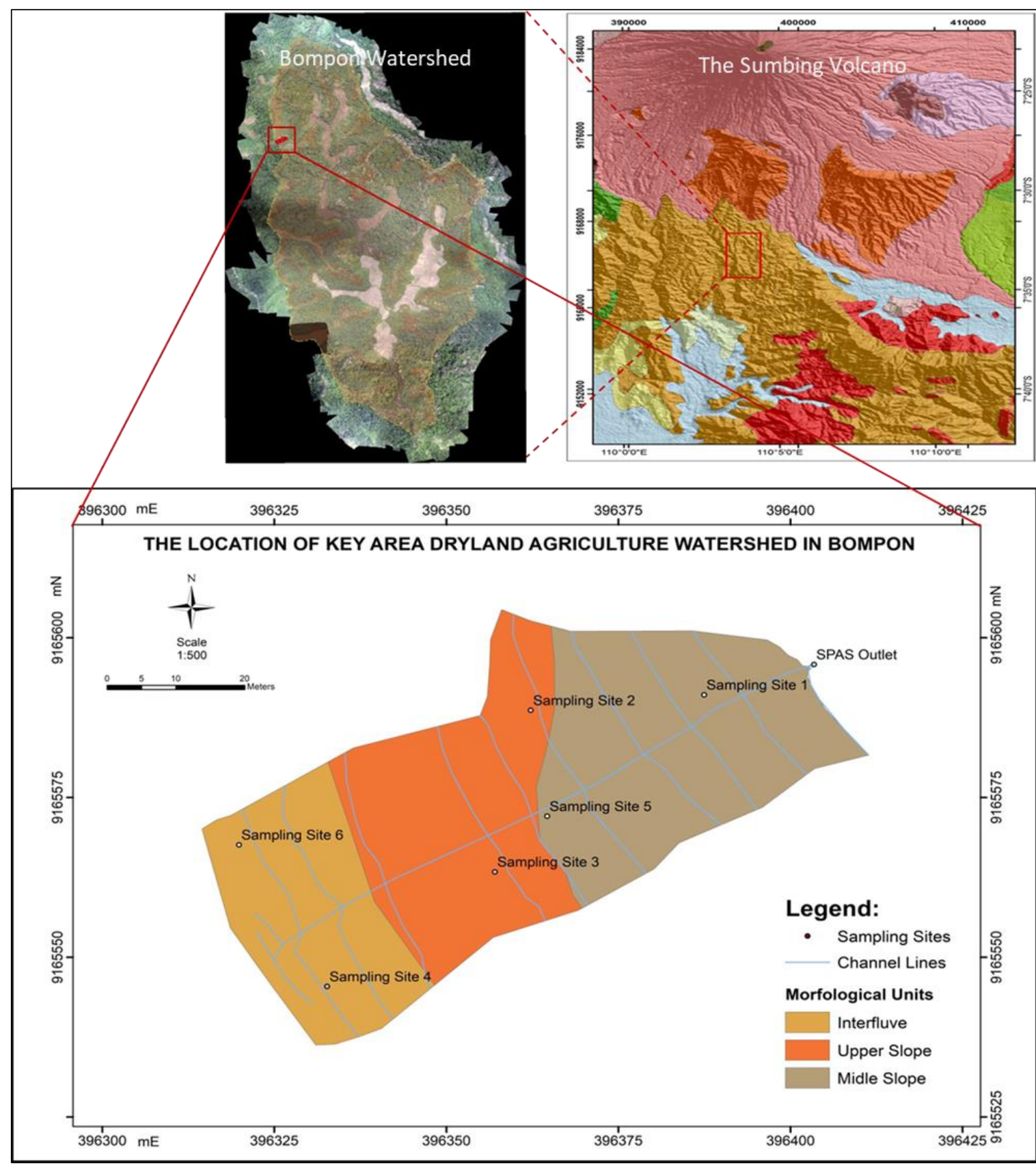

Figure 1. Locations of Key Areas in Bompon, a Volcanic Watershed for dryland agriculture 
The area is geomorphologically located in the foot slope of Sumbing volcano, with rolling to hilly topographies, and is infiltrated by a volcanic intrusion, which causes the bedrock to experience intensive alteration. Furthermore, the combination of this process and weathering has the capacity to generate a super thick soil layer, that is more than 10 meters, with high clay contents. Bompon vegetation cover is primarily an aspect of an agro-forestry system known to cultivate various tree species, including durian, coconut, sea hibiscus (Hibiscus tiliaceus), mahogany, Chinese albizia (Albiziachinensis), rosewood, Gnetumgnemon, Lansiumdookoo, Lansiumdomesticum cv. Kokossan, jackfruit, teak, bamboo, banana, salak (Salaccazalacca), turmeric, ginger and cardamom. In the lower stand layers, creeping surface plants, such as grass and galangal, are observed. Multi-level vegetation stands of various heights create a very dense and wide canopy spanning between 1-12 m, with a multilayer covering. However, the erosion occurrence in agro-forestry varies significantly, although its rate appears relatively mild (Hadini et al., 2019).

Dryland agriculture in Bompon volcanic watershed has started to intensively support human lives amid the increasing economic pressures and reduced movement capacity of other commercial sources. This system generally cultivates seasonal crops, such as cassava, maize, peanuts and vegetable, although the cultivation practices leave the soil surface relatively open, leading to an increase in erosion hazard and the concomitant sediment flow.

This study employed a field survey to identify the soil measurement, slope morphology and the characteristics of the sample land for dryland agriculture. The suspension flow was measured at the gully outlet, using a natural plot, such as a catchment gully watershed. Also, the sediment flow, comprising suspended sediments and bed loads was evaluated at every rainfall event for \pm two (2) years, resulting in 169 pairs of suspension data for model building and another 130 data pairs for verifications.

Rainfall conditions and water level suspension flow were recorded with an Automatic Rain Recorder (ARR) and Automatic Water Level Recorder (AWLR), respectively. This was followed by representing the resulting data in tables and graphs to describe the relationship between rainfall and sediment flow. Subsequently, a sediment flow analysis was conducted, depending on the water level and suspension flow, while the suspension data was analyzed using the filtration method, where the suspension weight and concentration were determined. The multiplication of this concentration by flow rate resulted in the suspension discharge for each water level flow rate (Wulandari et al., 2014). Meanwhile, the flow discharge was obtained by observing the water level at a broad-crested weir installed at the outlet and then calculated using weir discharge equation (Herschy, 2009). The flow discharge at a particular 
water level and the sediment concentration at a certain interval were correlated with the suspended sediment discharge. This relationship was modeled into a sediment discharge curve, which refers to a regression line between sediment discharge and flowrate, using the Eq. 1 (Wulandari et al., 2014):

$$
\mathrm{Q}_{\mathrm{s}}=\mathrm{aQ} \mathrm{Q}^{\mathrm{b}}
$$

Where: Qs= sediment discharge $(\mathrm{g} / \mathrm{s})$; and $\mathrm{Q}=$ flowrate $(1 / \mathrm{s})$.

The water level data was plotted into a flow hydrograph to provide information on the flow rate at each rainfall, while the hydrograph and water level data formed a graph representing the relationship between the water level and the stage-discharge rating curve of Eq.1. Flow rate data were used to determine sediment discharge, although both the flow and sediment discharge generated a sediment-discharge rating curve. However, to plot the sediment discharge curve (suspension), the flow rate and sediment discharge data were positioned on $\mathrm{x}$ and $\mathrm{y}$ axes, respectively. The plotted data described a series of instantaneous correlation between flow and suspended sediment discharges, and further analyzed to identify the average suspension discharge as a function of the average flow rate at each rainfall. This was followed by statistically evaluating the calculations for the relationship analysis, using Microsoft Excel 2010, with correlation and regression test features (Santoso, 2007). Furthermore, the sedimentation process produced erosion and sediment values that indicates the level of watershed degradation. These indicators were determined from SDR with the Eq. 2 (Ayuningtyas, 2012):

$$
\mathrm{D}=\mathrm{SDR}=\mathrm{Y} / \mathrm{T}
$$

where $\mathrm{D}=$ sediment delivery ratio; $\mathrm{Y}=$ sediment yield obtained at watershed outlets (ton/ha/yr); $\mathrm{T}=$ total erosion of the catchment area (ton/ha/yr).

The SDR value was then calculated from the watershed area, using formula by Boyce (1975) in Eq. 3:

$$
\mathrm{SDR}=0,41 \mathrm{~A}^{-0,3}
$$

where SDR= sediment delivery ratio; $\mathrm{A}=$ watershed area (ha) 


\section{Results and Discussion}

This study focused on the sediment flow in a volcanic watershed for dryland agriculture encompassing several challenges, including the relationship pattern between sediment flow (suspension discharge) and water level (flow discharge), the sediment discharge rate and soil loss, as well as the sediment source type.

\subsection{The Relationship between Suspension and Flow Discharges}

The relationship pattern between the suspension discharge and water level is presented in the form of a correlation between suspension discharge and flow rate. This is possible considering that changes in the water level influences the flow rate. Meanwhile, the alterations in the flow rate tend to control the changes in the suspension discharge.

\subsubsection{The Relationship between Flow Discharge and Water Level}

Based on the land utilized for dryland agriculture, the relationship between flow rate and water level generated a flow rate model with an equation $Q=0.9328 \mathrm{~h}^{1.5247}$. Figure 2 represents the determination coefficient of the curve at $\mathrm{R}^{2}=0.9999$. This flow discharge model was developed from 299 pairs of flow rate and water level data. Meanwhile, the value of $\mathrm{R}^{2}=0.99$ indicates that the flow rate variations were influenced by $99 \%$ of water level change and $1 \%$ of other factors.

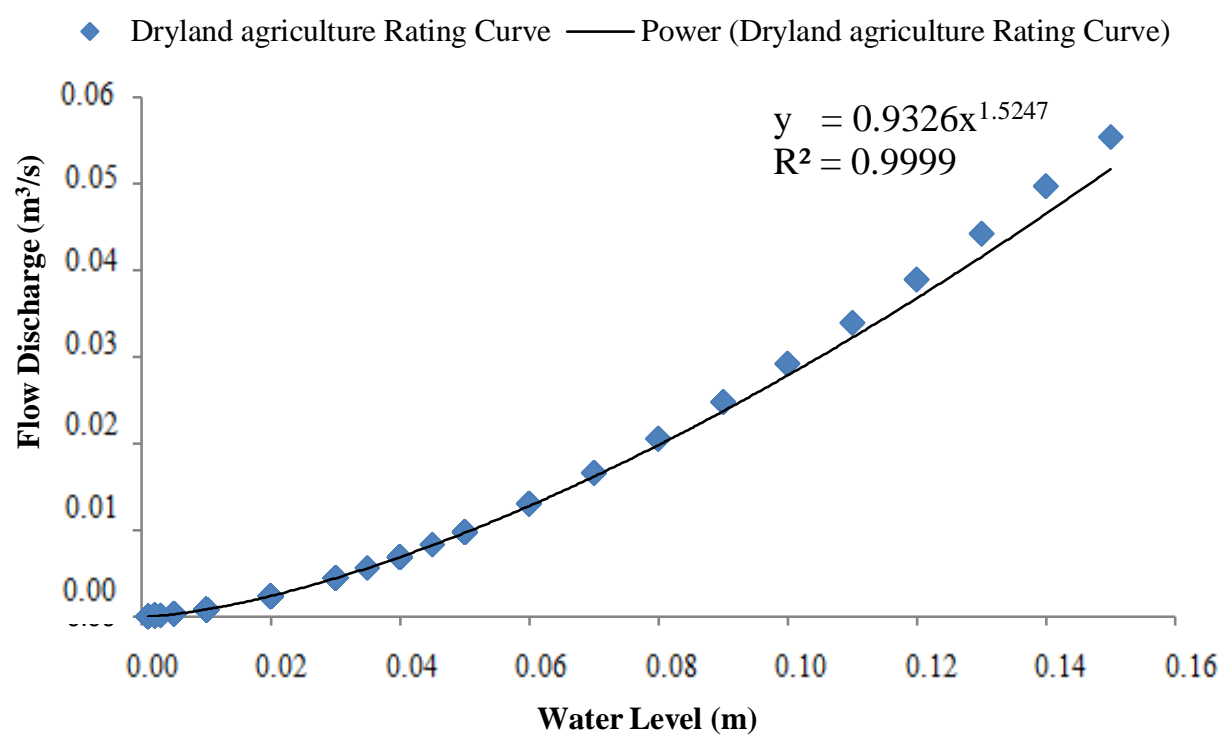

Figure 2. Flow discharge model of water level in the key area for dryland agriculture in bompon watershed 
The $\mathrm{t}$-test resulted in $\mathrm{t}_{\text {hit }}=-0.163$ and the use of Microsoft Excel application obtained $\mathrm{t}_{\mathrm{tab}}=\mathrm{t}_{\text {inv }}(0.05 ;(299-1))=1.97$. This $\mathrm{t}_{\text {hit }}$ value appeared minimal, compared to $\mathrm{t}_{\mathrm{tab}}$, indicating no significant difference between the discharge with direct field measurement and the counterpart from the flow curve analysis. Therefore, the flow discharge model on super thick soil in upper volcanic slopes with dryland agriculture fulfilled the requirements in flow rate calculation for various outlet water levels. The observation data analysis and the flow curve model calculation generated an average flow rate of 1.64 and $1.61 \mathrm{~m}^{3} / \mathrm{sec}$, respectively. Also, the difference between the observed and the modeled flow rate was $0.0034 \mathrm{~m}^{3} / \mathrm{s}$, indicating a percentage error (deviation) of 2.04\%. According to Widasmara \& Hadi (2016), the allowable deviation value occurs between $10-20 \%$. Therefore, the flow rate model in this study appears suitable for predicting the watershed flow discharge, with deviation value probably above $10 \%$. This is because the data distribution in building the model has been altered, including the zero water level value during the measurement. Field observation showed that the zero water-level change also tends to occur, due to the sediment accumulation.

This circumstance influences the flow morphology upstream of the gauging station. Also, the sediment accumulation contained sand and silt capable of altering the flow morphology during rainfall. The error sources responsible for producing irregularities, involved the use of mean value in daily flow calculations, although the calculation does not represent the peak discharge. Suripin (2000) stated that the use of flow rating curves from the mean value of a series of daily discharge data possibly generates $50 \%$ or more errors. The deviation value in this study was more preferred compared to the previously reported flow rate model. This deviation is probably caused by the cross-sectional channel properties responsible for triggering the sediment, or a control section. In a centralized control section, the downstream channel flow appears centered because its basic morphological shape experiences channel narrowing (Soewarno, 1991; Gao et al., 2017).

\subsubsection{The Relationship between Suspension Discharge and Flow Discharge}

The flow discharge model in the form of a flow curve type in dryland agriculture $(\mathrm{Q}=$ $0.9328 \mathrm{~h}^{1.5247}$ ) was used to simulate a suspension sediment discharge in the study area. Figure 3 shows that the suspended sediment discharge and the flow discharge produced a polynomial relationship, $\mathrm{Q}_{\mathrm{s}}=0.0349 \mathrm{Q}^{2}+5.9374 \mathrm{Q}-1.0601$, with a determination coefficient ofR $^{2}=0.82\left(\mathrm{Q}_{\mathrm{s}}=\right.$ Suspension discharge $(\mathrm{g} / \mathrm{s}) ; \mathrm{Q}=$ Flow discharge $\left.(1 / \mathrm{s})\right)$. As a consequence, the suspension flow variations were possibly described as the influence of $82 \%$ flow rate factors 
and $18 \%$ other determinants. The $\mathrm{t}$-test of the suspension curve model yielded $\mathrm{t}_{\text {hit }}=-0.000605$, while the Microsoft Excel results obtained $t_{t a b}=t_{\text {inv }}(0.05 ; 299-1)=1.97$. Furthermore, the $t_{\text {hit }}$ value appeared minimal, compared to $t_{t a b}$, indicating no significant difference between the field measured suspension discharge and the simulated value from the suspension curve model.

- Curve of Suspension Discharge

— Poly. (Curve of Suspension Discharge)

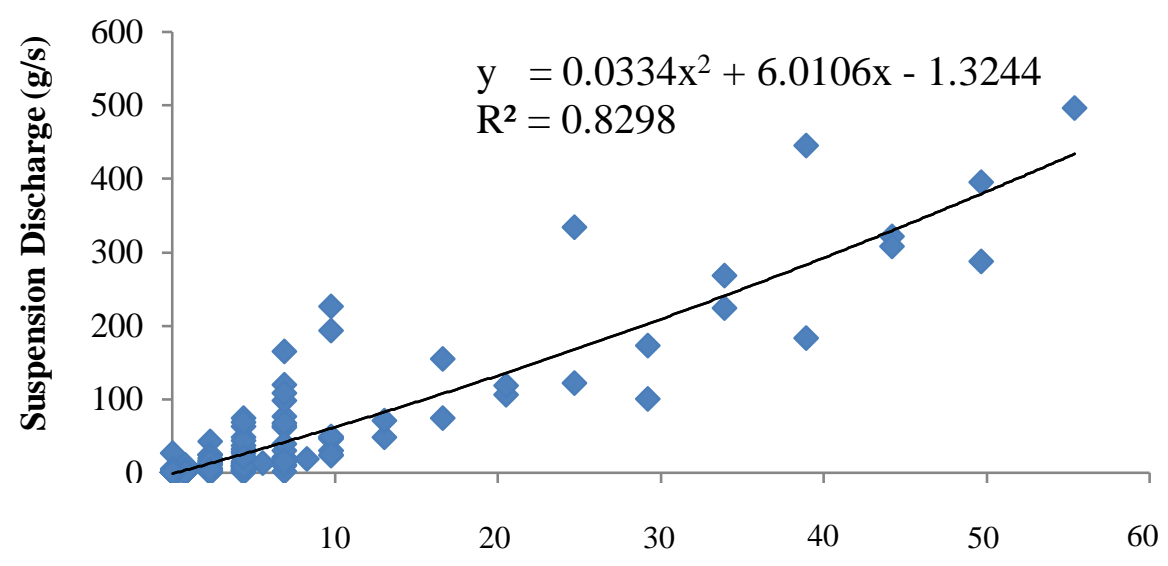

Flow Discharge (1/s)

Figure 3. Graph of the suspension discharge model and flow discharge at the dryland agriculture in bompon watershed

The results of the suspension sediment calculations from the suspension discharge model matched the requirements for assessing the suspension discharge at various water levels, with error rate at approximately $18 \%$. Particular factors known to contribute to these errors include the sampled sediment and discharge concentrations using conventional tools that potentially did not measure the overall suspension, leading to smaller values, and secondly, limited time interval for the sampling discretization, specifically during highintensity rainfall with rapid flow rate changes. However, the need to address the vulnerabilities by correcting both error sources appears very significant. The modification is also performed by examining the data quality, specifically based on the requirements in data homogeneity and outliers (Wulandari et al., 2014; Neno et al., 2016; Yan et al., 2015). 


\subsubsection{Verification of Suspension Discharge Model}

The suspension discharge model was verified to ensure the consistency of its application. This process was conducted by collecting suspension and water level samples in similar gauging stations at different time intervals from January-March 2018. The t-test results showed that the discharge curve model was not applicable to the overall rainfall states, although the two test conditions obtained $\mathrm{t}_{\mathrm{stat}}=-4.066$, that is, greater than $\mathrm{t}_{\mathrm{tab}}=1.969$. Subsequently, various rain conditions were analyzed, including the low-moderate and highextreme rainfall occurrences. This test was aimed at determining the possibility of a consistent suspension discharge model under certain rain conditions (low-moderate or highextreme). The results showed a stable suspension discharge model only in low-moderate rainfall, as evidenced in the test value $t_{S t a t}=1.1478$ (smaller than $t_{t a b}=1.996$ ). This finding indicatesthat the suspension discharge model in areas of dryland agriculture appears applicable only for water level variations in low-moderate rainfall.

\subsection{Calculation of Flow Discharge and Suspended Sediment Discharge}

\subsubsection{Calculation of Flow Rate and Suspension Sediment Discharge on AWLR}

The suspension discharge model was used to obtain a suspension discharge for the flow rate $(\mathrm{Q})$ of each water level. This parameter was calculated from the individual daily, monthly, and annual flow rates recorded by AWLR. The daily suspension discharge refers to the average of suspension discharge in a day, while its summation in a month is called the average monthly suspension discharge. Consequently, the variation of the monthly suspension discharge in a year is possibly identified. Meanwhile, the unit adjustment in expressing the suspension discharge as an annual period is achieved by converting $\mathrm{g} / \mathrm{s}$ to tons/year, using a multiplier of 31.536. Table 1 presents the average monthly suspension discharge for a year at $262.01 \mathrm{ton} / \mathrm{yr}$, with an average flow rate of $1.80 \mathrm{~L} / \mathrm{s}$. The maximum suspension flow discharge at 563.34 ton/yr, occurred in May during raining season. This event produced a flow rate of $3.64 \mathrm{~L} / \mathrm{s}$, while the minimum occurrence in September, 20.77 ton/yr, also in raining season, generated the lowest flow rate of $0.10 \mathrm{~L} / \mathrm{sec}$. Therefore, rainfall factors that control the flow rate conditions are very influential towards sediment flow (suspension) and soil loss in a volcanic watershed mainly used for dryland agriculture. In summary, each rainfall event demonstrated different characteristics with separate flow rates and suspension discharges. Based on the suspension flow rate model calculation, a significant difference was observed in the suspension discharge for different flow rates. 
Table 1. Average flow rate $(\mathrm{Q})$ and Suspension Discharge $\left(\mathrm{Q}_{\mathrm{s}}\right)$ based on Dryland Agriculture Practices in the Watershed Key

\begin{tabular}{|c|c|c|c|c|c|c|c|c|c|c|}
\hline \multirow{3}{*}{ No } & \multirow{3}{*}{ Months } & \multicolumn{3}{|c|}{$\begin{array}{c}\text { Flow Discharge Q } \\
(\mathrm{L} / \mathrm{s})\end{array}$} & \multicolumn{3}{|c|}{$\begin{array}{c}\text { Suspension Discharge Qs } \\
\text { (Ton/yr) }\end{array}$} & \multicolumn{3}{|c|}{$\begin{array}{c}\text { Total Suspension Qs/A } \\
(\text { Ton/ha/yr) }\end{array}$} \\
\hline & & \multicolumn{2}{|c|}{ Year } & \multirow{2}{*}{ Average } & \multicolumn{2}{|c|}{ Year } & \multirow{2}{*}{ Average } & \multicolumn{2}{|c|}{ Year } & \multirow{2}{*}{ Average } \\
\hline & & 2017 & 2018 & & 2017 & 2018 & & 2017 & 2018 & \\
\hline 1 & January & - & 3.00 & 3.00 & - & 390.78 & 390.78 & - & 1207.46 & 1207.46 \\
\hline 2 & February & - & 2.09 & 2.09 & - & 286.83 & 286.83 & - & 886.26 & 886.26 \\
\hline 3 & March & - & 1.98 & 1.98 & - & 285.31 & 285.31 & - & 881.58 & 881.58 \\
\hline 4 & April & - & 0.10 & 0.10 & - & 40.24 & 40.24 & - & 124.33 & 124.33 \\
\hline 5 & May & 5.85 & 1.03 & 3.44 & 984.33 & 70.50 & 527.42 & 3041.46 & 217.85 & 1629.65 \\
\hline 6 & June & 1.33 & 1.34 & 1.33 & 173.94 & 171.60 & 172.77 & 537.46 & 530.22 & 533.84 \\
\hline 7 & July & 0.84 & 0.42 & 0.63 & 76.06 & 19.96 & 48.01 & 235.03 & 61.68 & 148.35 \\
\hline 8 & August & 0.84 & 0.31 & 0.57 & 76.06 & 55.40 & 65.73 & 235.03 & 171.19 & 203.11 \\
\hline 9 & September & 0.39 & 0.57 & 0.48 & 5.86 & 35.69 & 20.77 & 18.09 & 110.28 & 64.19 \\
\hline 10 & October & 2.07 & 1.67 & 1.87 & 352.10 & 238.61 & 295.35 & 1087.93 & 737.27 & 912.60 \\
\hline 11 & November & 1.42 & 5.85 & 3.64 & 152.34 & 984.33 & 568.34 & 470.73 & 3041.46 & 1756.09 \\
\hline \multirow[t]{4}{*}{12} & December & 4.77 & 0.10 & 2.44 & 879.32 & 5.86 & 442.59 & 2716.99 & 18.09 & 1367.54 \\
\hline & Average & & & 1.80 & & & 262.01 & & & 809.59 \\
\hline & $\operatorname{Max}$ & & & 3.64 & & & 568.34 & & & 1756.09 \\
\hline & Min & & & 0.10 & & & 20.77 & & & 64.19 \\
\hline
\end{tabular}

Note: $\operatorname{ton} / \mathrm{yr}=31.536 \mathrm{~g} / \mathrm{s}$

The suspension discharge in dryland agricultural areas appeared relative extensive, strongly reflecting the suspended sediments as well as the study area conditions. Field observations indicated that the flow at the gauging station drained the suspension with reasonably large sediment at every rain event, particularly with high intensity and lengthy durations. The watershed capacity to store and drain water into the soil in these regions was considerably minimal, leading to the flow stoppage immediately after the rain. Furthermore, the annual distribution of the suspended sediments in the sample areas observed two (2) peak periods, termed May and November. In both months, the rain occurrence appeared more frequent with high intensity, resulting in extensive average flow rates.

\subsubsection{Calculation of Sediment Discharge and Soil Loss}

Sediment discharge known to instigate soil loss,occurs in the form of sediment load and also refers to the accumulation of all sediment types, including the suspended sediments and bedloads into the channel outlet. The sediment load was subsequently calculated depending on the weight of suspended sediment and bed loads from the field data measurement and analysis. Table 2 shows an average sediment load of 86,660.11 g, comprising sediments and bed loads of $81,385.04 \mathrm{~g}$ and 6,045.02 g, respectively. 
Table 2. Calculation of sediment discharge and soil loss

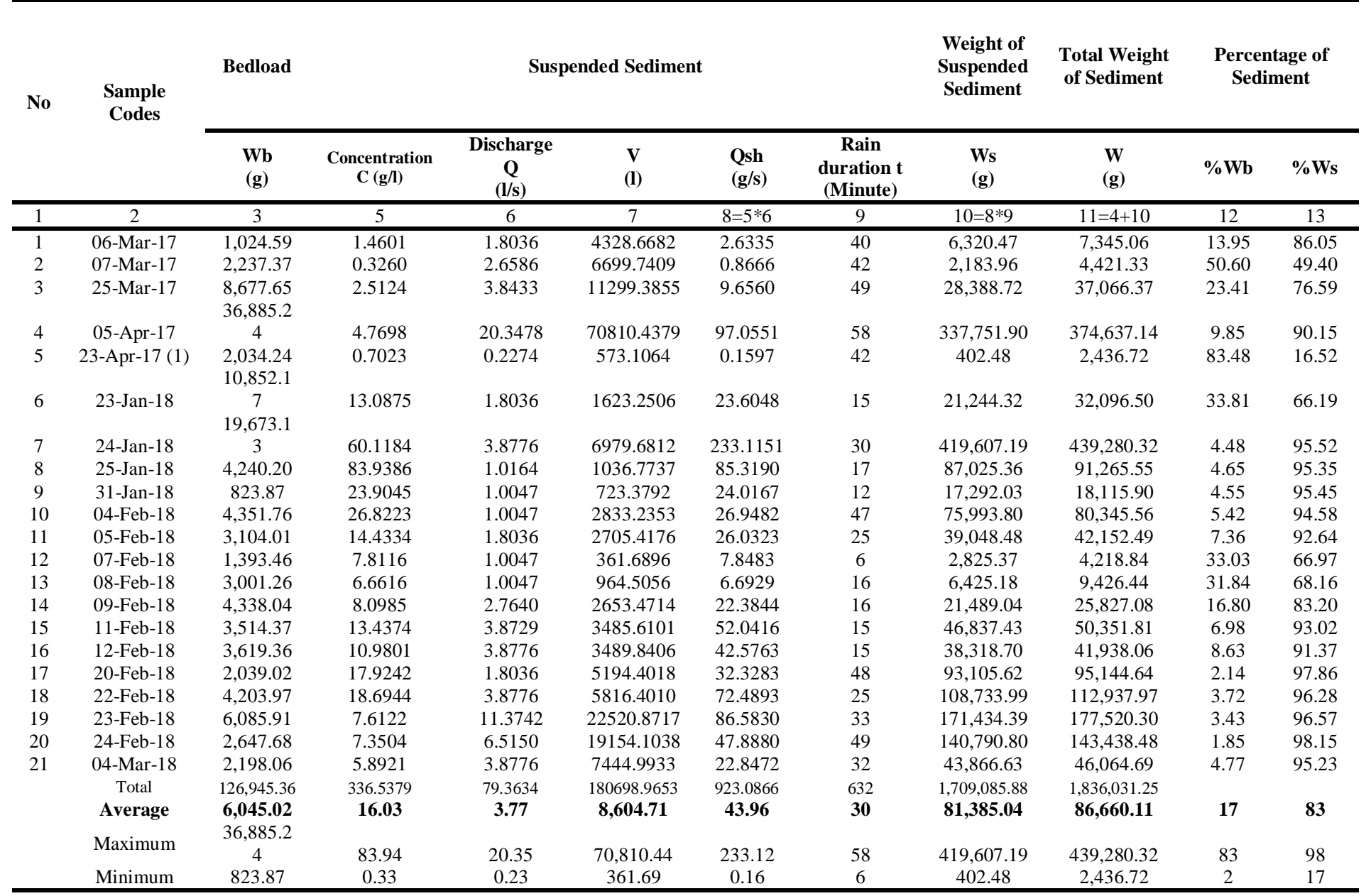

Note: $\mathrm{Q}=\mathrm{Cd}^{*} \mathrm{Cv}^{*}((9.8))^{\wedge}(1 / 2)^{*} \mathrm{~b}^{*}((\mathrm{~h}))^{\wedge}(3 / 2) ; \mathrm{Ws}=(\mathrm{Qs} * 60) * \mathrm{t} ; \mathrm{V}=\left((\mathrm{Qs} /(24 * 60))^{*} \mathrm{t}\right.$

\section{3 The Type of Sediment Source Material during the Flow}

The percentage of suspended sediment loads in the study area varied from 17-98\%, with an average of $83 \%$, while the bed load composition to sediment loads ranged between $2-83 \%$, with an average of $17 \%$. These bed loads have been estimated using the Borland \& Maddocktables (1951), based on the concentration and grading of suspended sediments in the forms of clay, silt and sand provided the bed load composes $20 \%$ of the suspended materials (Soewarno, 1991). The ratio of bed load to the suspended sediments $(6,045.02 / 81,385.04)$ was estimated at 0.0698 or $7.5 \%$, while the average bed load of $7.5 \%$ x $308.60=23.14$ ton/yr, was obtained using similar ratio for the mean value of the annual suspension discharge in Table 1. This study further achieved a bed load discharge of approximately 331.74 ton/yr.

The comparison between the sediment yields in the channels and soil erosion is defined as SDR (Ayuningtyas, 2012; Lazzari et al., 2015). According to Ma'wa et al., (2009), the relationship between the characteristics of the catchment area and SDR is calculated using 
Eq. 3. The results also generated a watershed key area of 0.324 ha, while the SDR obtained 0.2472, while the rate or total soil loss was based on the sediment yield, or sediment discharge per unit area $(331.74 \mathrm{ton} / \mathrm{yr}) /(0.324 \mathrm{ha})=953.53 \mathrm{ton} / \mathrm{ha} / \mathrm{yr}$. Eq. 2 was used to generate the total erosion rate in the watershed key area at 1,657.94 ton/ha/yr.

This study indicated that high flow rates were able to influence the sediment flow and erosion process in dryland agriculture areas, leading to soil loss (Sambodo \& Arpornthip, 2021). The extent to the effect of flow discharge on the sediments is significantly dependent on erosion, particularly the soil erodibility (Morgan, 2005; Hadini et al., 2019). Soil erodibility refers to a complex property that is based on soil infiltration rate and its capacity to withstand detachment by raindrops and scouring by surface runoff. This parameter is strongly influenced by the state of the soil structure (Renard et al., 1997), organic matter, texture and soil permeability (Desifindiana et al., 2013). Based on the soil texture, fine sand and silt fractions are soil particles possibly affecting soil erodibility (Morgan, 2005; Rusdi et al., 2013; Hadini et al., 2021).

In dryland agricultural areas of Bompon volcanic watershed, the super thick soil is characterized by surface silt-clay and clay texture, with a range of compositions, including sand $7-3 \%$, silt $14-58 \%$ and clay $34-57 \%$. Table 3 shows the soil permeability occurrence in the moderate category, with an average of $4.23 \mathrm{~cm} / \mathrm{hr}$ as well as the bulk density ranging between $0.97-1.20 \mathrm{~g} / \mathrm{cm}^{3}$, averaged at $1.11 \mathrm{~g} / \mathrm{cm}^{3}$. Figure 4 is a map representation of the soil texture distribution in the study area. Based on the dominance of soil texture by clay fractions, a volcanic watershed extensively utilized for dryland agriculture, is classified as hardly erodible. However, the total sediment yield was estimated at 953.53 ton/ha/yr, while the overall watershed erosion attained 1,657.94 ton/ha/yr, which was categorized as 'very heavy' erosion rate (Departemen Kehutanan, 1986). The observation results showed that in dryland applications, certain differences in the sediment discharge were observed at each rain event. These variations occurred with distinct flow rates that are controlled by the rain intensity and duration. Furthermore, the consistency test (t-test) outcomes reported a strong and positive correlation between sediment discharge (suspension) and flow rate, indicating a more intensive land erosion process in triggering sediment flow and soil loss, compared to the erosion effects (scouring) at the bottom of the channel and base load. This statement corresponded to Leopold \& Maddock (1953), where a robust association between suspended sediment and flow discharge signified a more intensive land erosion process in triggering sediment flow than the erosion (scouring) in the canal and on the bed load. 
Table 3. Characteristics of surface soil for dryland agriculture watershed

\begin{tabular}{|c|c|c|c|c|c|c|c|c|c|c|}
\hline \multirow{2}{*}{ No. } & \multirow{2}{*}{$\begin{array}{c}\text { Soil } \\
\text { Characteristics }\end{array}$} & \multirow{2}{*}{ T1 } & \multirow{2}{*}{$\mathbf{T 2}$} & \multirow{2}{*}{ T3 } & \multirow{2}{*}{ T4 } & \multirow{2}{*}{ T5 } & \multirow{2}{*}{ T6 } & \multicolumn{3}{|c|}{$\begin{array}{c}\text { Dryland Agriculture } \\
\text { Watershed }\end{array}$} \\
\hline & & & & & & & & Max & Min & Average \\
\hline 1 & Sand (\%) & 13.3443 & 9.2377 & 8.5904 & 9.1651 & 7.7635 & 6.9694 & 13 & $\overline{7}$ & 9 \\
\hline 2 & Silt (\%) & 14.1041 & 37.2408 & 39.2815 & 56.3412 & 41.3775 & 14.9183 & 56 & 14 & 33 \\
\hline 3 & Clay (\%) & 72.5517 & 53.5215 & 52.1281 & 34.4937 & 50.8590 & 78.1123 & 78 & 34 & 57 \\
\hline 4 & $\begin{array}{l}\text { Soil texture } \\
\text { classification } \\
\text { (USDA) }\end{array}$ & Clay & $\begin{array}{l}\text { Silty } \\
\text { Clay } \\
\text { Loam }\end{array}$ & $\begin{array}{l}\text { Silty Clay } \\
\text { Loam }\end{array}$ & Clay & $\begin{array}{l}\text { Silty } \\
\text { Clay }\end{array}$ & $\begin{array}{l}\text { Silt } \\
\text { Loam }\end{array}$ & - & - & Clay \\
\hline 5 & $\begin{array}{l}\text { Permeability } \\
\text { (cm/hour) }\end{array}$ & 4.966 & 1.433 & 0.601 & 8.223 & 8.412 & 1.764 & 8.41 & 0.60 & 4.23 \\
\hline 6 & $\begin{array}{l}\text { Permeability } \\
\text { classification }\end{array}$ & $S$ & $\mathrm{AL}$ & $\mathrm{AL}$ & $\mathrm{AC}$ & $\mathrm{AC}$ & $\mathrm{AL}$ & $\begin{array}{c}\text { Fairly } \\
\text { fast }\end{array}$ & $\begin{array}{l}\text { Fairly } \\
\text { slow }\end{array}$ & Fair \\
\hline 7 & $\begin{array}{l}\text { Bulk density } \\
\qquad\left(\mathrm{g} / \mathrm{cm}^{3}\right)\end{array}$ & 1.201 & 1.068 & 1.168 & 1.156 & 0.971 & 1.083 & 1.20 & 0.97 & 1.11 \\
\hline
\end{tabular}

Note: $\mathrm{T}=$ Sampling sites at the dryland agriculture

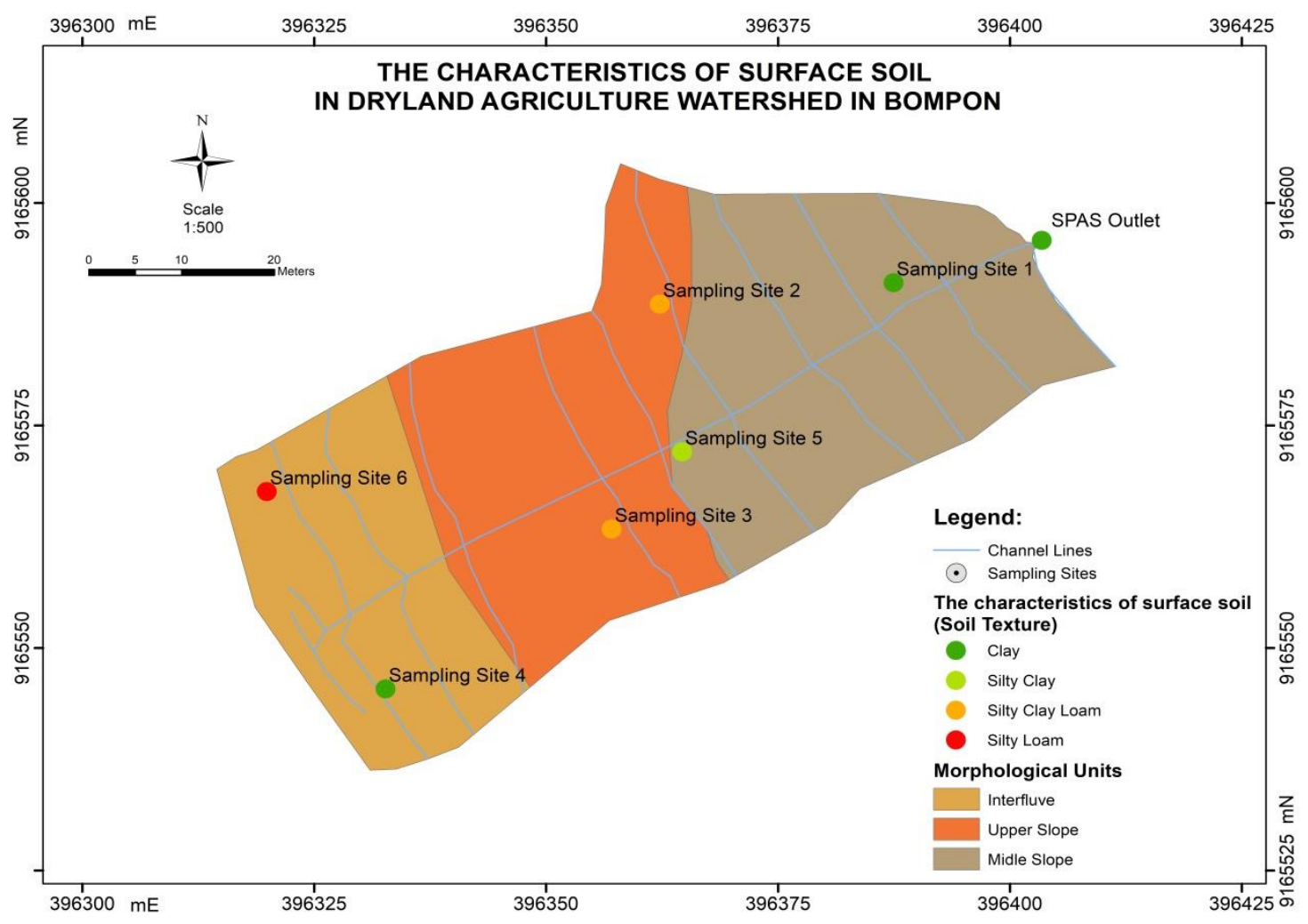

Figure 4. Distribution of soil texture characteristics in the research areas

Rainfall factors and geophysical conditions are known to strongly influence flow discharge, which controls erosion. This process induces sediment flow and soil loss in the watershed key area primarily utilized for dryland agriculture.Sediment flow is also regulated by the dynamics of rain characteristics, such as intensity and duration. An important aspect of 
the study of sediment flow in the upper watershed region refers to the assessment of the sediment flow characteristics under different land uses, including agroforestry, settlements and dryland agriculture. This study obtained distinct sediment flow for these land use types as a response of the dynamics of the land's geophysical characteristics to specific rainfall.The process commenced with a rain event, known to trigger the breakdown of soil aggregates, leading to splash and sheet erosion. Alongside the increase in rainfall intensity and duration, the accumulation of surface flow becomes more intense, leading to rillerosion, gullyerosion, and sediment transport to the channel outlet (Verstraeten, et al., 2007; Gumiere, et al., 2015). Therefore, the conservation of land resources against erosion and sedimentation effects is expected to prioritize proactive measures towards reducing the raindrop energy and rill erosion occurrence by an extensive rate of concentrated flow.

\section{Conclusion}

The sediment flow characteristics in volcanic landscape slopes with dryland land use characterized by (1) The relationship pattern between the suspension discharge and flow rate possibly used according to the change in flow rate of the suspension discharge by generating a curved model of the suspension discharge curve $\mathrm{Qs}=0.0322 \mathrm{Q}^{2}+6.0625 \mathrm{Q}-1.2658$; (2) Sediment flow that causes very heavy erosion rates by producing an average soil loss rate of 1,657.94 tons/ha/year; (3) Suspension and bed load sediments as the dominant type of soil loss sediment sources, with contribution rates of $83 \%$ and 17\%, respectively; (4) Soil loss sources with a more dominant proportion of suspended sediments indicating further widespread soil losses due to land erosion processes in the watershed areas, compared to the counterparts from the groove erosion process and channel bed loads.

\section{Conflict of interest}

The authors declare that there is no conflict of interest with any financial, personal, other people or organizations related to the material in this study.

\section{Acknowledgements}

The authors are grateful to the relevant parties for assisting in the study implementation and paper preparation, specifically the Indonesia Endowment Fund for Education (LPDP) for financially supporting the doctorate study of the authors. Further appreciations are extended to the staffs and technicians of the soil laboratory for their assistance during the laboratory analysis process, in addition to the translucent team that 
helped with field activities and supporting information on the study area in Bompon Watershed.

\section{References}

Ahn, J., \& Yang, C. (2015). Determination of recovery factor for simulation of nonequilibrium sedimentation in reservoir. International Journal of Sediment Research, 30(1), 68-73. https://doi.org/10.1016/S1001-6279(15)60007-5.

Alstrom, K. \& Akerman, A. B. (2016).Contemporary Soil Erosion Rates on Arable Land in Southern Sweden. Geografiska Annaler: Series A, Physical Geography,74(2), 101108. https://doi.org/10.1080/04353676.1992.11880354.

Ayuningtyas, D.W.(2012). Analisis Pengaruh Curah Hujan Terhadap Sedimentasi di Daerah Aliran Sungai (DAS) Citarum Hulu dengan Metode RUSLE. Doctoral Dissertation. Institut Teknologi Bandung.

Badan Geologi Indonesia. (2011). Data Dasar GunungApi Indonesia, Edisi ke-2. Bandung : Kementrian Energi dan Sumber Daya Mineral.

Bachri, S., Utaya, S., Nurdiansyah, F.D., Nurjanah, A.E., Tyas, LWN.,Purnama, D.S., \& Adillah, A.A. (2017). Analisis dan Optimalisasi Potensi Lahan Pertanian sebagai Kajian Dampak Positif Erupsi Gunungapi Kelud 2014. Majalah Geografi Indonesia, 31 (3), 33-43. https://doi.org/10.22146/mgi.27738.

Boyce, R. C. (1975). Sediment routing with sediment delivery ratios. In Present and prospective technology for predicting sediment yields and sources, pages 61-65. US Department of Agriculture, Publication ARS-S-40.

Departemen Kehutanan (1986). Pedoman Penyusunan Rencana Teknik Lapang Rehabilitasi Lahan dan Konservasi Tanah Daerah Aliran Sungai. Jakarta: Direktorat Jenderal Reboisasi dan Rehabilitasi Lahan.

Desifindiana, M.D., Suharto, B., \& Wirosoedarmo, R. (2013). Analisa Tingkat Bahaya Erosi pada DAS Bondoyudo Lumajang dengan Menggunakan Metode Musle (In Press). Jurnal Keteknikan Pertanian Tropis dan Biosistem, 1(2), 9-17.

Gao, P., Deng, J.,Chai, X., Mu, X., Zhao, G., Shao, H., \& Sun, W. (2017). Dynamic sediment discharge in the Hekou - Longmen region of Yellow River and soil and water conservation implications. Science of the Total Environment, 578, 56-66. http://dx.doi.org/10.1016/j.scitotenv.2016.06.128.

Gumiere, S.J., Bailly, J.S., Cheviron, B., Raclot, D., Bissonnais, Y.L., \& Rousseau, A.N. (2015). Evaluating the Impact of the Spatial Distribution of Land Management Practices on Water Erosion: Case Study of a Mediterranean Catchment. J. Hydrol. Eng., 20(6), 1-10. https://doi.org/10.1061/\%28ASCE\%29HE.1943-5584.0001076.

Hadini, L.O., Sartohadi, J., Setiawan, M., \& Mardiatno, D. (2019).Characteristics of sediment flow and soil loss of the volcanic landscape watershed with agroforestry landuse, Ecology, Environment and Conservation Paper, 25(3), 1062-1071. 
Hadini, L.O., Sartohadi, J., Setiawan, M.A., \& Mardiatno, D. (2021). The Dynamics of Flow Discharge and Suspension Flow Discharge in Volcano Watershed with Agroforestry Land Cover. Civil and Environmental Science Journal (Civense), 4(2), 141-153. https://doi.org/10.21776/ub.civense.2021.00402.4.

Herschy, R.W. (2009). Streamflow Measurement Third edit. Abingdon : Routledge.

Kellner, E., \& Hubbart, J. A. (2018).Spatiotemporal variability of suspended sediment particle size in a mixed-land-use watershed. Science of the Total Environment, 615, 1164-1175. https://doi.org/10.1016/j.scitotenv.2017.10.040.

Lazzari, M., Gioia, D., Piccarreta, M., Danese, M., \& Lanorte, A. (2015). Sediment yield and erosion rate estimation in the mountain catchments of the Camastra artificial reservoir (Southern Italy): A comparison between different empirical methods. Catena, 127, 323-339. http://dx.doi.org/10.1016/j.catena.2014.11.021.

Leopold, L.B. \& Maddock, T. (1953). The Hydraulic Geomtry of Stream Channels and Some Physiographic Implications. Washington : US Government Printing Office.

Li, X., Wang, H., Zhang, L., \& Wu, B. (2015).Soil Erosion and Sediment-Yield Prediction at Basin Scale in Upstream Watershed of Miyun Reservoir. J. Hydrol. Eng., 20(6), 17. https://doi.org/10.1061/(ASCE)HE.1943-5584.0001098.

Maalim, F.K., Melesse., A.M, Belmont, P., Karen, \& B. Gran. (2013). Modeling the impact of land use changes on runoff and sediment yield in the le sueur watershed, minnesota using GeoWEPP. Catena, 107, 35-45. https://doi.org/10.1016/j.catena.2013.03.004.

Ma’wa, J., Andawayanti, U., \& Juwono, P.T. (2009). Studi Pendugaan Sisa Usia Guna Waduk Sengguruh Dengan Pendekatan Erosi dan Sedimentasi. Doctoral Dissertation. Univeristas Brawijaya.

Maltsev, K., \& Yermolaev, O. (2020).Assessment of soil loss by water erosion in small river basins in Russia. Catena, 195. https://doi.org/10.1016/j.catena.2020.104726.

Mondal, A., Khare, D., Kundu, S., Meena, P. K., Mishra, P. K., \& Shukla, R. (2015). Impact of Climate Change on Future Soil Erosion in Different Slope , Land Use, and SoilType Conditions in a Part of the Narmada River Basin , India. J. Hydrol. Eng., 20(6): C5014003, 20(2003), 1-12. https://doi.org/10.1061/(ASCE)HE.19435584.0001065 .

Morgan, R.P.C. (2005). Soil Erosion and Conservation: Third Edition. USA : Blackwell.

Nandini, R. \& Narendra, B.H. (2012). Karakteristik Lahan Kritis Bekas Letusan Gunung Batur di Kabupaten Bangli, Bali. Jurnal Penelitian Hutan dan Konservasi Alam, 9(3), 199-211.

Neno, A. K., Harijanto, H., \& Wahid, A. (2016). Hubungan Debit Air Dan Tinggi Muka Air di Sungai Lambagu Kecamatan Tawaeli Kota Palu. Warta Rimba, 4(2) 1-8. 
Nocoń, W. (2016). Quantitative monitoring of batch sedimentation based on fractional density changes. Powder Technology, 292, 1-6. https://doi.org/10.1016/j.powtec.2016.01.010.

Panagos, P, Borrelli, P, Poesen, J, Ballabio, Lugato, E., Meusburger, K., Montanarella, L., \& Allewl, C. (2015). The new assessment of soil loss by water erosion in Europe. Environmental Science \& Policy, 54, 438-447. http://doi.org/10.1016/j.envsci.2015.08.012.

Renard, K.G., Foster, G.R., Wesies, G.A., Mc Cool, D.K., \& Yoder, D.C. (1997). Predicting Soil Erosion by Water: A Guide to Conservation Planning With the Revised Soil Loss Equation (RUSLE). Washington DC: US Department of Agriculture.

Rusdi, R., Alibasyah, M. R., \& Abubakar, K. (2013). Evaluasi Degradasi Lahan Diakibatkan Erosi Pada Areal Pertanian di Kecamatan Lembah Seulawah Kabupaten Aceh Besar. Jurnal Konservasi Sumber Daya Lahan, 1(1), 24-39.

Sambodo, A. P., \& Arpornthip, T. (2021). Increasing the Efficiency of Detailed Soil Resource Mapping on Transitional Volcanic Landforms Using a Geomorphometric Approach. Applied and Environmental Soil Science, 2021. https://doi.org/10.1155/2021/8867647.

Santoso, S. (2007). Mengolah Data Statistik Secara Profesional. Jakarta: Elex Media Komputindo.

Sartohadi, J. (2013). Genesis Tanah Super Tebal dan Kaitannya dengan Longsor Dalam di Hulu DAS Bogowonto Jawa Tengah. LPPM UGM : Yogyakarta.

Sartohadi, J., \& Pratiwi, E.S. (2014). Bunga Rampai Penelitian: Pengelolan Bencana Kegunungapian Kelud pada Periode Krisis Erupsi 2014. Yogyakarta: Pustaka Pelajar.

Sharma, A., Tiwari, K.N. \& Bhadoria, P.B.S. (2011). Effect of land use land cover change on soil erosion potential in an agricultural watershed. Environ Monit Assess, 173, 789801. https://doi.org/10.1007/s10661-010-1423-6.

Soewarno. (1991). Hidrologi Pengukuran dan Pengukuran Daerah Aliran Sungai. Bandung: Nova.

Suripin, S. (2000). Evaluasi Penggunaan Teknik Debit-Lengkung Sedimen dalam Memprediksi Sedimen Layang. Jurnal dan Pengembangan Keairan, 1, 35-43.

Utomo, M. M. B., Suryatmojo, H.,\& Soedjoko, S.A. (2014). Kajian Pengaruh Karakteristik Hujan Terhadap Volume Aliran dan Berat Suspensi di Kawasan Karst. Widyariset, 15(3),527-534.

Verma, A. K., \& Jha, M. K. (2015). Evaluation of a GIS-Based Watershed Model for Streamflow and Sediment-Yield Simulation in the Upper Baitarani River Basin of Eastern India. J. Hydrol. Eng., 20(6). https://doi.org/10.1061/(ASCE)HE.19435584.0001134. 
Verstraeten, G., Prosser, I. P., \& Fogarty, P. (2007). Predicting the spatial patterns of hillslope sediment delivery to river channels in the Murrumbidgee catchment, Australia. Journal of Hydrology, 334(3-4), 440-454. http://doi.org/10.1016/j.jhydrol.2006.10.025.

Widasmara, M.Y., \& Hadi, M.P. (2016).Pemodelan debit aliran DAS Bompon menggunakan metode rasional modifikasi. Jurnal Bumi Indonesia, 5(3), 1-13.

Wulandari, D.A., Suripin, \& Syafrudin.(2014). Evaluasi Penggunaan Lengkung Laju DebitSedimen (Sediment-Discharge Rating Curve) Untuk Memprediksi Sedimen Layang. Doctoral dissertation. Universitas Diponegoro.

Yan, Q., Lei, T., Yuan, C., Lei, Q., Yang, X., Zhang, M., Su, G., \& An, L. (2015). Effects of watershed management practices on the relationships among rainfall, runoff, and sediment delivery in the hilly-gully region of the Loess Plateau in China. Geomorphology, 228, 735-745. https://doi.org/10.1016/j.geomorph.2014.10.015.

Zhou, H., Chang, W., \& Zhang, L. (2016). Sediment sources in a small agricultural catchment: A composite finger printing approach based on the selection of potential sources. Geomorphology, 266, 11-19. https://doi.org/10.1016/j.geomorph.2016.05.007. 